\title{
J. C. VAN ROOY.
}

Op 29 Augustus 1954 het sag ontslaap Johannes Cornelis van Rooy, vroeër Professor in die Wysbegeerte en later in die Sosiale Wetenskappe, nog later Rektor en daarna tot sy dood Kanselier van die Potchefstroomse Universiteit vir Christelike Hoër Onderwys.

By die vermelding van die heengaan van prof. dr. J. C. van Rooy, alombemind en deurgaans bekend as Johannes, meestal verkort as Joon, van Rooy, is daar een gevoel wat hom van die hart van 'n mens meester mak: dit is die gevoel van opregte, treurende dankbaarheid.

Die besef dat hierdie opregte vriend, hierdie beminde volksman, hierdie oortuigde kerkman, hierdie dierbare geleerde tot hoër diens deur sy Here wat sy hele lewe bestuur het, opgeroep is, laat 'n mens wat hom van naby geken het, in alle opregtheid treur, maar laat 'n mens wat saam met hom geleef en gewerk het, in kinderlike opregtheid dank. Ons treur, omdat hy nie meer onder ons is en ons nie meer sy leiding sal ervaar nie. Maar ons dank, omdat hy onder ons was en ons sy leiding gehad het. Die Here het in hom aan almal, alle vriende en geesgenote, alle goeie Suid-Afrikaners, alle opregte gelowiges, alle nederige geleerdes gegee 'n voorbeeld om na te volg

By 'n vinnige lewensbeeld van Johannes van Rooy, wat so getrou aan die werklikheid en so sober moontlik wil wees, is daar veral vier dinge wat bo alle ander dinge uitstaan. Die vier dinge is die skoonste karaktertrekke van die oorledene. Hulle is agtereenvolgens: sy blanke opregtheid en edelmoedigheid, sy innige en oortuigde lewenskeuse, die vurigheid van sy gees, en die diepte en egtheid van sy geleerdheid.

Sy blanke opregtheid en edelmoedigheid het uitgegaan na vriend en vyand. Sy hart en sy huis het altyd wyd oopgestaan vir almal wat by hom steun en raad wou inwin. Hy het geen onderskeid geken tussen oud en jong, ryk en arm, hooggeplaas en onontwikkeld nie. Selfs diegene wat nie met hom saamgegaan het nie, kon hom met vrymoedigheid nader. Hy het 'n groot oop hart gehad, 'n toegeneë oor en 'n hart wat verstaan. Hy het vertroue ingeboesem. juis omdat hy almal vertrou het. Hy het nooit enige vrees aangejaag, omdat hy self geen vrees geken het nie. Hy was sagmoedig en genaakbaar, juis omdat hy self nie geskroom het om sy teerste gedagtes en sy diepste gevoelens aan andere te openbaar nie. Geheimsinnigheid en geestelike gereserveerdheid het ' $n$ mens nie by hom gevind nie. 
Sy innige en oortuigde lewenskeuse het uitgeblink in die helderheid en beslistheid van sy lewens- en wêreldbeskouing. Sy lewenskeuse het sy wortel gevind in die vrome huislike vorming en opvoeding, en dit is gevoed deur die diepte en grondigheid van sy ootmoedige vroomheid. Wat van essensiële betekenis is, is die feit dat sy lewe sy leer gedra het: hy het nie regs gedink en dan links geloop nie! Sy pad is voorafbepaald en vooruitgerig: daar was ' $n$ koers in sy leer en lewe! Hy het geweet waar om te begin, hy het geweet waar hy heen moet en hy het geweet hoe om daar te kom!

Die vurigheid van sy gees het uitgestraal uit die branding van sy gees in die oortuigdheid van sy gevoel en sy verstand. Ja, hy het 'n groot oop hart gehad, hy wás sagmoedig en edelmoedig, hy wás onvervals opreg, maar hy het 'n wil gehad so vas as 'n rots! As 'n saak sy belangstelling ontvang het, as die saak met sy oortuiging gestrook het, as dit dié oortuiging sou bevestig en uitbrei, dan was hy 'n onvermoeide, onversetlike en geïnspireerde en inspirerende yweraar. Hy kom vlammend en gloeiend praat: dit was mooi en goed; maar hy kon drywend handel, die woord in die daad omsit; dit was mooier en beter! Die Here het hom 'n diep insig in lewensvrae gegee, maar Hy het hom ook die kragtigwerkende gawe van die daad, die organisasie en administrasie gegee.

Die diepte en egtheid van sy geleerdheid het in die eerste plek dag vir dag tot sy intieme vriende en tot sy studente gespreek. Maar dit het in die tweede plek ook oor die grense van die akademiese beperktheid gegaan. Almal wat met hom in aanraking gekom het, het onder die bekoring van sy diep en egte geleerdheid geraak. Sy groot boekgeleerdheid, wat werklik omvangryk was, is egter gedra deur sy nog groter denkkrag en lewensvisie. In hom het saamgeleef en saamgegroei tot 'n hegte eenheid kennis en wysheid, sodat hy hom aan almal getoon het as dié ideale opgevoede mens.

Hierdie kort woord van waardering en huldiging oor 'n heengegane vriend en medewerker, volksman, kerkman en geleerde kan saamgevat word in ' $n$ afsluitende eenheidsbeeld van Johannes Cornelis van Rooy:

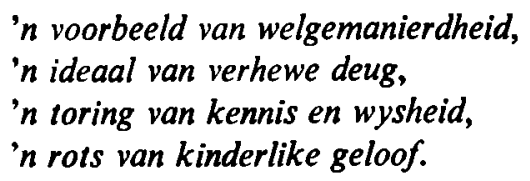

J. CHR. COETZEE.

S.A.U.K.,

30 Augustus 1954. 